\title{
Factors affecting profitability of small-scale vegetable production in the Visayas
}

\author{
Annie D. Centes, Jessa H. Ruales, Rhena Jane Soria and Moises Neil V. Seriño ${ }^{1 *}$
}

\begin{abstract}
This study was conducted to assess the profitability of small-scale vegetable production in the Visayas, particularly in the islands Leyte, Samar and Bohol. The data used in the study was taken from baseline survey on vegetable production in the Visayas. Descriptive, correlation and multiple regression analyses were used in analysing factors that influence profitability. Results show that significant factors that affect profitability include cropping practices and market outlets. This suggests that profitability of small-scale vegetable production measured in terms of gross margins will tend to increase with the practice of multi-cropping and intercropping systems. With limited farm size, farmers can maximize the yield of vegetable production through intercropping and multi-cropping practice. In addition, primary market outlet affects profitability implying that better access to market translates to higher profitability. Results of the study suggest that to improve profitability of farmers in Leyte, Samar and Bohol, policy makers, researchers and technician should focus on optimizing cropping system. Farmers should be trained to identify vegetables that produces better yield in an intercropping and multi-cropping system. This should also be complemented with better access to market. Farm to market road should be improved so that farmers can easily link their production to the market.
\end{abstract}

Keywords: profitability, market access, vegetable farmers, cropping system

\section{INTRODUCTION}

Vegetables are loaded with vitamins and minerals that contribute to growth and the maintenance of good health. Vegetables may help reduce risk for heart disease, including heart attack and stroke. Most vegetables are naturally low in fat and calories. One of the main health benefits of vegetables is their high nutrient content, including potassium, dietary fiber, folate (folic acid), vitamin A, and vitamin C. Diets rich in potassium may help to maintain healthy blood pressure. Vegetable sources of potassium include sweet potatoes, white potatoes, white beans,

'Department of Economics, Visayas State University

\footnotetext{
* Corresponding Author. Address: Department of Economics, Visayas State University, Visca, Baybay City, Leyte, Philippines; Email:moisesneil.serino@vsu.edu.ph DOI: $10.32945 /$ atr39sb16.2017
} 
tomato products (paste, sauce, \& juice), beet greens, soybeans, lima beans, spinach, lentils, and kidney beans (Barrett 2006).

Despite the health benefits of vegetables, it's consumption in the Philippines is currently estimated at only $39 \mathrm{~kg}$ per capita, well below the $146-182 \mathrm{~kg}$ per capita recommended by the World Health Organization (WHO). Majority of fresh vegetables in the Philippines (75-85\%) are sold through the traditional marketing system, where farmers sell their produce on the spot market to traders, consolidators, vegetable processors and wholesalers in the wet market. The supermarket share of the local vegetable market is just $10 \%$, (Batt et al 2005).

The average farm size in the Philippines is just 2.02 hectares and it is very difficult for smallholder vegetable farmers to access institutional market. Inconsistent supply, poor quality, low prices, unfavorable terms of payment and penalties associated with non-compliance are some of the problems faced by small-scale vegetable farmers. Poor quality is a multifaceted problem that has root causes at the farm level and post-farm gate. This includes poor quality seed, poor cultural practices, excessive insect and disease damage, inappropriate postharvest handling, the high cost of inputs and limited access to finance. Furthermore, most smallholder vegetable farmers are unaware of the quantities of vegetables planted, the customers' quality requirements, preferred varieties, the seasonality of production and the supply and demand situation in both domestic and export markets (Carating et al 2010).

Addressing the demands and the current problems of the industry requires resources. The Visayas region has the smallest area (approximately $56,606 \mathrm{~km}^{2}$ ) among the three major regions of the Philippines. The climatic conditions are unpredictable which needs to be considered especially in planting seasonal crops (Amongo 2011). In this regard, this study seeks to answer the following questions: (i) how profitable is the vegetable production of small-scale farmers in the Visayas? (ii) what were the factors that affect the profitability of their production? And (iii) what were the key determinants of the vegetable profitability? Specifically, this study will particularly evaluate the profitability of farmers growing the following selected vegetables: tomato, sweet pepper, eggplant and bitter gourd. These vegetables are commonly planted in the Visayas region.

\section{METHODOLOGY}

\section{Data Used}

The data used in the study was taken from the Australian Center for Intenational Agricultural Research (ACIAR) funded project conducted by Visayas State University on protected vegetable production. The study focuses on enhancing profitability of vegetable farmers in the Philippines using integrated crop management approach (McDougall \& Rogers 2012). This is a project implemented by Visayas State University (VSU) together with several collaborating agencies. Area covered by the project includes the vegetable farmers from Samar, Leyte and Bohol. Small-scale vegetable farmers were the respondents of the study. The respondents were randomly selected from the farmers trained under the farmer field school (FFS) and other respondents were non-FFS or farmers that were not part of the training to serve as control group. The total number of respondents in different areas of Leyte, Samar and Bohol is $\mathbf{3 1 1}$ farmers. These 311 farmers are 
composed of $221 \mathrm{FFS}$ participants and 90 non-FFS farmers (Seriño et al 2017). Figure 1 shows the location of farmers included in the study.

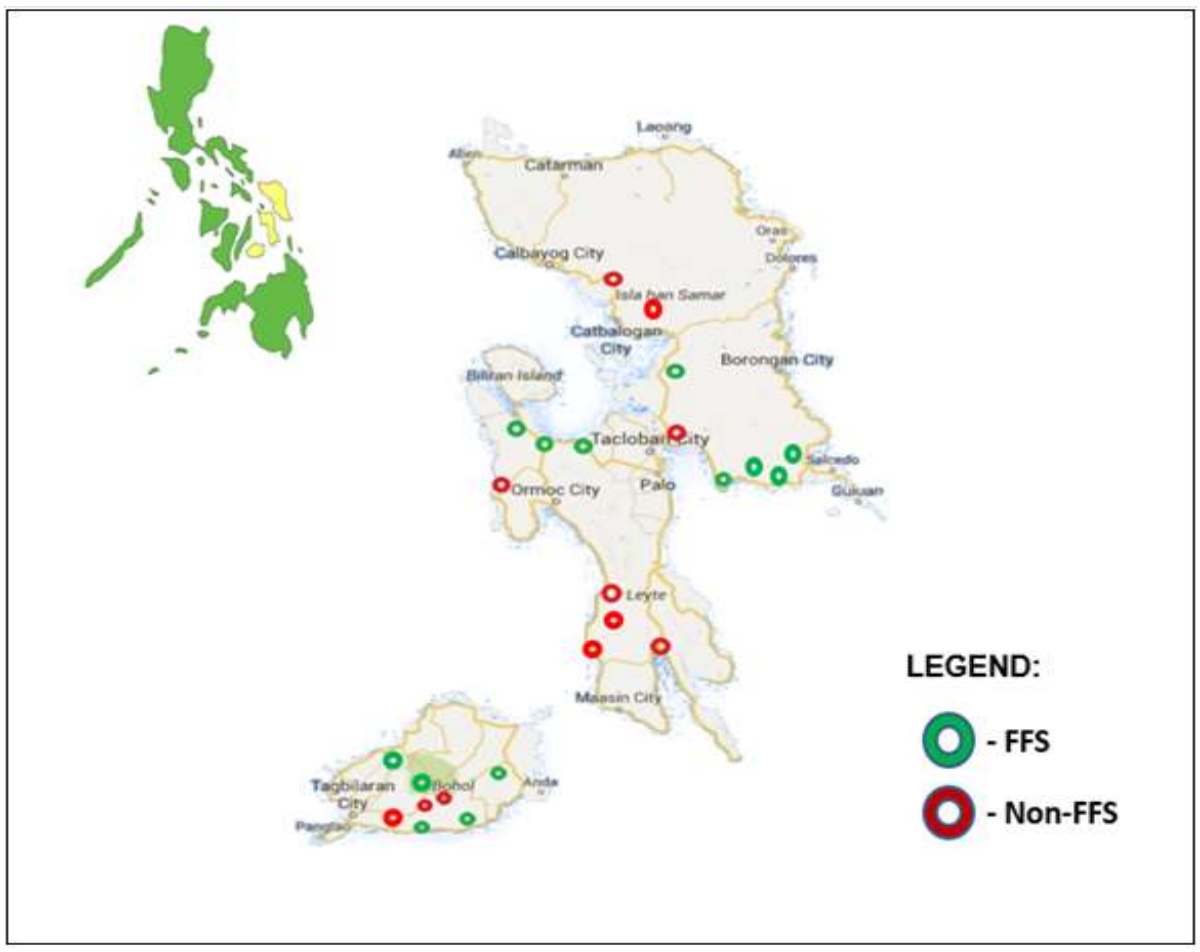

Figure 1. Location of the project sites (Source: Seriño et al 2017)

\section{Gross Margin (GM)}

Gross margin analysis (GMA) is probably one of the most widely used method in assessing profitability. Gross margin is frequently used to calculate the profitability of different farm enterprises and technologies. It can be used to calculate the profitability of growing an entirely new crop if a farmer wishes to diversify production. It can be used to project future profitability as part of the farmers' planning (Jagelavicius 2013). However, computation of gross margin does not include fixed cost. It only accounts the variable cost. This approach is practical in assessing profitability of small-scale vegetable farmers because smallscale farmers do not have the capacity to invest in big production facilities and equipment. Small-scale production costs mostly include only variable costs. Gross margin is calculated as follows:

$$
\text { Gross Margin = Gross Income }- \text { Variable Cost }
$$

where:

gross income $=$ product price multiplied by the quantity of produce vegetable

variable cost $=$ total cost incurred such as labor cost, material cost, transport and others

gross margin $=$ the profit after deducting expenses and costing incurred 
Factors affecting profitability of small-scale vegetable production in the Visayas

\section{Regression Approach}

To analyze the profitability in vegetable production, the method of multiple regression analysis was employed. Regression analysis is a statistical technique that attempts to explore and model the relationship between a dependent variable and two or more independent variables. A regression is a statistical analysis assessing the association between two variables (Seriño 2017). It is to find the relationship between two variables. For this study, the profitability function of smallscale vegetable production is expressed as follows:

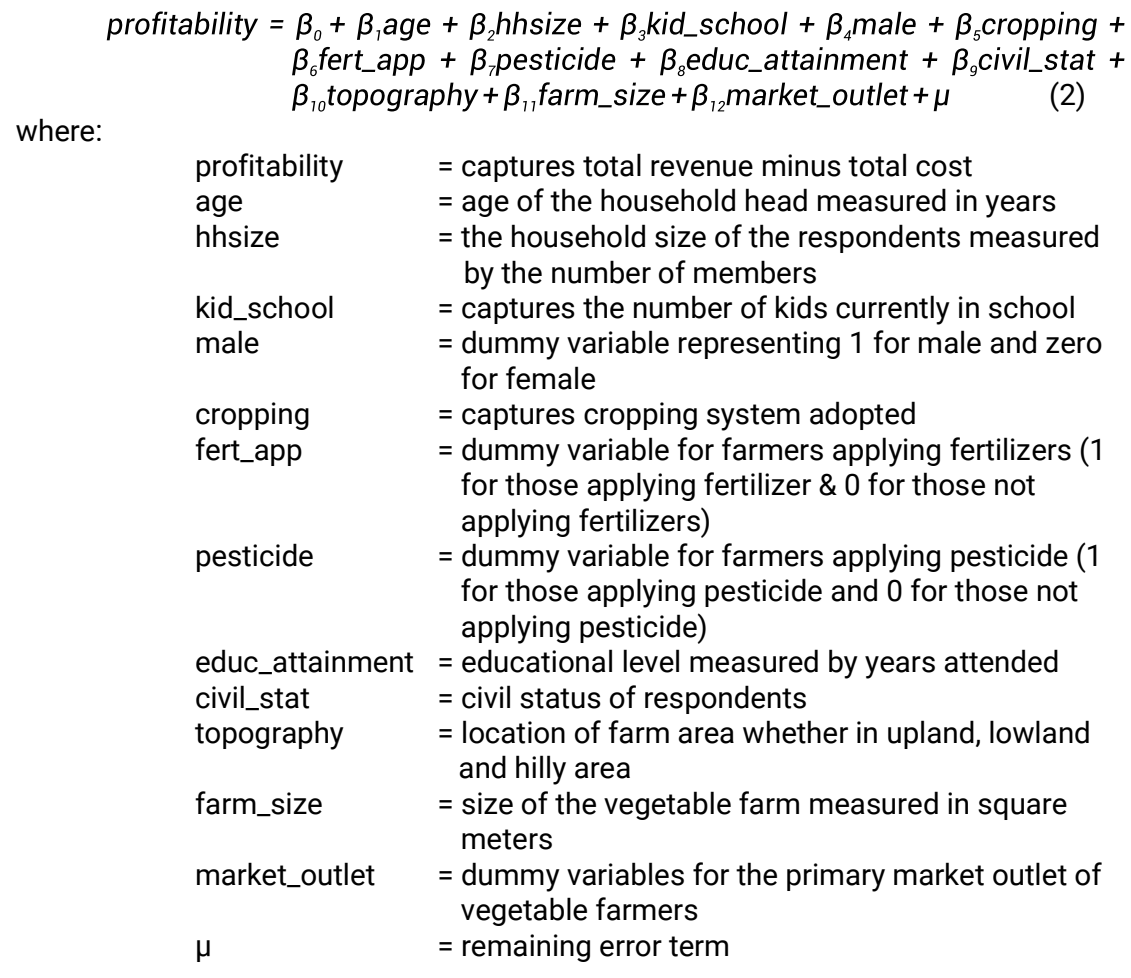

\section{RESULTS AND DISCUSSION}

\section{Socio-Demographic Characteristics}

Table 1 presents the selected demographic characteristics of the 311 vegetable farmers in the Visayas. Majority of the respondents in three provinces were aged 41 - 60 years old with an average age of 49 years old for Leyte and 50 years old for Samar and Bohol. About $80 \%$ of the farmer respondents were males. In Leyte, $84.6 \%$ of the respondents are married while for Bohol are $87.3 \%$ and Samar farmers are close to $95 \%$. Most of the respondents finished either elementary education or secondary level of education. The average households' size of the farmers in Bohol and Leyte is five (5) while for Samar the average household size is six (6). Table 1 shows the summary of socio-demographic characteristics of farmers included in the study. 
Centes et al

Table1. Socio-demographic characteristics of 187 vegetable farmers in the Visayas

\begin{tabular}{|c|c|c|c|c|c|c|}
\hline \multirow{2}{*}{ Characteristics } & \multicolumn{2}{|c|}{ Leyte } & \multicolumn{2}{|c|}{ Samar } & \multicolumn{2}{|c|}{ Bohol } \\
\hline & $\mathrm{n}$ & $\%$ & $\mathrm{n}$ & $\%$ & $\mathrm{n}$ & $\%$ \\
\hline \multicolumn{7}{|l|}{ a. Age } \\
\hline 20 and below & 0 & 0.0 & 1 & 1.0 & 0 & 0.0 \\
\hline $21-40$ & 21 & 27.3 & 19 & 19.6 & 21 & 16.7 \\
\hline $41-60$ & 43 & 55.8 & 62 & 63.9 & 86 & 68.3 \\
\hline 61 and above & 13 & 16.9 & 15 & 15.5 & 19 & 15.1 \\
\hline Total & 77 & 100.0 & 97 & 100.0 & 126 & 100.0 \\
\hline Mean (years) & \multicolumn{2}{|c|}{48.71} & \multicolumn{2}{|c|}{49.93} & \multicolumn{2}{|c|}{49.96} \\
\hline \multicolumn{7}{|l|}{ b. Gender } \\
\hline Male & 60 & 76.9 & 81 & 76.4 & 104 & 81.9 \\
\hline Female & 18 & 23.1 & 25 & 23.6 & 23 & 18.1 \\
\hline Total & 78 & 100.0 & 106 & 100.0 & 127 & 100.0 \\
\hline \multicolumn{7}{|l|}{ c. Civil status } \\
\hline Single & 3 & 3.8 & 4 & 3.9 & 1 & 0.8 \\
\hline Married & 66 & 84.6 & 89 & 87.3 & 120 & 94.5 \\
\hline Widowed & 4 & 5.1 & 5 & 4.9 & 4 & 3.1 \\
\hline Separated & 2 & 2.6 & 0 & 0.0 & 1 & 0.8 \\
\hline Live-in & 3 & 3.8 & 4 & 3.9 & 1 & 0.8 \\
\hline Total & 78 & 100.0 & 102 & 100.0 & 127 & 100.0 \\
\hline \multicolumn{7}{|c|}{ d. Educational attainment } \\
\hline No grade completed & 0 & 0.0 & 0 & 0.0 & 1 & 0.8 \\
\hline Elementary Level & 39 & 52.7 & 45 & 47.9 & 58 & 49.2 \\
\hline Secondary Level & 26 & 35.1 & 35 & 37.2 & 40 & 33.9 \\
\hline College Level & 8 & 10.8 & 8 & 8.5 & 9 & 7.6 \\
\hline Degree Holder & 1 & 1.4 & 6 & 6.4 & 10 & 8.5 \\
\hline Total & 74 & 100.0 & 94 & 100.0 & 118 & 100.0 \\
\hline \multicolumn{7}{|l|}{ e. Household size } \\
\hline $1-3$ & 17 & 21.8 & 15 & 14.2 & 31 & 24.4 \\
\hline $4-6$ & 47 & 60.3 & 55 & 51.9 & 69 & 54.3 \\
\hline $7-9$ & 12 & 15.4 & 28 & 26.4 & 22 & 17.3 \\
\hline$>10$ & 2 & 2.6 & 8 & 7.5 & 5 & 3.9 \\
\hline Total & 78 & 100.0 & 106 & 100.0 & 127 & 100.0 \\
\hline Mean & \multicolumn{2}{|c|}{4.81} & \multicolumn{2}{|c|}{5.73} & \multicolumn{2}{|c|}{5.00} \\
\hline
\end{tabular}


Factors affecting profitability of small-scale vegetable production in the Visayas

\section{Farm Area of Vegetable Production}

Table 2 shows the average farm area measured in square meter per farmer. On average, Bohol farmers have the smallest land area devoted for planting vegetables compared to Samar and Leyte areas. For tomato, Bohol has the lowest farm area with an average close to $325 \mathrm{~m}^{2}$. Leyte and Samar both have more than $500 \mathrm{~m}^{2}$ average farm area allocated for planting tomato. For sweet pepper, Leyte farmers had the largest land area $\left(945 \mathrm{~m}^{2}\right)$ and again Bohol had the smallest land area of $390.03 \mathrm{~m}^{2}$. For eggplant production, Samar farmers had the largest farm area of $1372.53 \mathrm{~m}^{2}$ while Bohol is still had the smallest area. On average, the farm area allotted for bitter gourd in Samar is $1238.48 \mathrm{~m}^{2}$ and still the highest of all provinces.

Table 2. Estimated average farm area of vegetable $\left(\mathrm{m}^{2}\right)$ per farmer in Leyte, Samar and Bohol

\begin{tabular}{lccc}
\hline Area $\left(\mathrm{m}^{2}\right)$ & Leyte & Samar & Bohol \\
\hline Tomato & 507.50 & 571.43 & 324.36 \\
Sweet pepper & 945.00 & 767.00 & 390.03 \\
Eggplant & 1154.00 & 1372.53 & 470.01 \\
Bitter gourd & 953.74 & 1238.48 & 566.76 \\
\hline Average & 890.06 & 987.36 & 437.79 \\
\hline
\end{tabular}

\section{Input Costs}

Vegetable farmers were aware that one way of increasing the quantity of their production is by applying the right amount of fertilizer. Essential nutrients which are presently absent in the soil could be supplemented. Most vegetable farmers usually use the following fertilizers: complete, vermicast, chicken dung, manure, urea, and calcium nitrate. For those who applied fertilizers, Table 3 shows the estimated average cost of fertilizer application per cropping by crop. It appears that Sweet pepper has higher fertilizer cost compared to other crops.

Table 3. Estimated cost of fertilizer application per cropping season

\begin{tabular}{lcrc}
\hline Crops & Leyte & Samar & Bohol \\
\hline Tomato & 1203.29 & 248.00 & 610.75 \\
Sweet pepper & 2668.92 & 1904.50 & 1043.14 \\
Eggplant & 2072.33 & 971.77 & 832.02 \\
Bitter gourd & 1384.00 & 557.90 & 1155.88 \\
\hline Average & 1832.14 & 920.54 & 910.45 \\
\hline
\end{tabular}

Labor includes man-days for hired labor and family labor. Labor cost considers the labor associated with soil preparation, seed-bed preparation, transplanting, fertilizer application, weeding control, pesticide application and harvesting. Table 4 shows the estimated labor cost in the production per crop. For growing tomato, the 3 provinces have incurred different cost. Leyte has relatively higher cost compared Samar and Bohol. Eggplant in For sweet pepper, Bohol and Leyte have lower 
expenses compared to Samar. For eggplant, Leyte has higher labor cost comparing to others. This is because of high labor cost, high fertilizer cost and cost associated with weed control. Meanwhile for bitter gourd, results showed that Leyte has relatively higher labor cost with PHP4175.73 compared to Samar and Bohol with PHP2432.46 and PHP2152.38 respectively.

Table 4. Average labor cost (Philippine peso) of four crops in Leyte, Samar and Bohol

\begin{tabular}{|c|c|c|c|}
\hline 1. Tomato & Leyte & Samar & Bohol \\
\hline Seed bed preparation & 675.00 & 442.86 & 270.45 \\
\hline Land preparation & 571.55 & 750.00 & 356.10 \\
\hline Transplanting & 585.97 & 364.29 & 190.51 \\
\hline Fertilizer application & 297.03 & 303.57 & 224.13 \\
\hline Weeding control & 789.16 & 317.86 & 256.26 \\
\hline Pesticide application & 160.73 & 256.25 & 154.78 \\
\hline Harvesting & 435.82 & 366.67 & 289.22 \\
\hline Total & 3515.26 & 2801.5 & 1741.45 \\
\hline \multicolumn{4}{|l|}{ 2. Sweet pepper } \\
\hline Seed bed preparation & 376.36 & 595.45 & 261.93 \\
\hline Land preparation & 394.84 & 684.62 & 480.53 \\
\hline Transplanting & 227.80 & 283.59 & 234.08 \\
\hline Fertilizer application & 348.47 & 296.59 & 298.69 \\
\hline Weeding control & 326.86 & 252.73 & 273.79 \\
\hline Pesticide application & 175.23 & 169.64 & 181.69 \\
\hline Harvesting & 206.81 & 525.00 & 343.83 \\
\hline Total & 2056.37 & 2807.62 & 2074.54 \\
\hline \multicolumn{4}{|l|}{ 3. Eggplant } \\
\hline Seed bed preparation & 627.41 & 517.30 & 277.33 \\
\hline Land preparation & 651.43 & 904.65 & 439.90 \\
\hline Transplanting & 421.29 & 335.09 & 260.56 \\
\hline Fertilizer application & 725.07 & 442.96 & 331.29 \\
\hline Weeding control & 1031.70 & 496.42 & 344.88 \\
\hline Pesticide application & 195.08 & 225.63 & 155.28 \\
\hline Harvesting & 530.56 & 555.42 & 568.72 \\
\hline Total & 4182.54 & 3477.47 & 2377.96 \\
\hline \multicolumn{4}{|l|}{ 4. Bitter gourd } \\
\hline Seed bed preparation & 493.55 & 249.52 & 367.45 \\
\hline Land preparation & 689.90 & 608.15 & 410.13 \\
\hline Transplanting & 502.32 & 262.41 & 241.72 \\
\hline Fertilizer application & 955.28 & 433.25 & 360.12 \\
\hline Weeding control & 955.28 & 433.25 & 360.12 \\
\hline Pesticide application & 206.49 & 109.89 & 161.62 \\
\hline Harvesting & 372.91 & 335.99 & 251.22 \\
\hline Total & 4175.73 & 2432.46 & 2152.38 \\
\hline
\end{tabular}


Factors affecting profitability of small-scale vegetable production in the Visayas

Transport costs include all the expenses in transporting inputs, materials and produce between farm and market. Table 5 shows the average transport cost from market to farm and vice versa. In Samar, the average transport cost is about PHP134 which is the highest among the three provinces. It is followed by Leyte with transport cost around PHP122. Bohol has relatively lower transport cost with an average of PHP78.54. The average distance from point of production to the market for Leyte is approximately $10 \mathrm{~km}$ and the average travel time is approximately 38 minutes (Table 6). For Samar the traveling time is around $22.13 \mathrm{~min}$ with a distance of $6.48 \mathrm{~km}$. The distance and travel time for Bohol is 7.36 and 25.25 respectively. In most of the three areas, their mode of transportations include "habal-habal", jeep, tricycle, truck and van, depending on the produce' amount and capacity. Others carry their produce by hand and deliver it to the buyer and this can explain why on average the travelling time is long even if it is only in a short distance.

Table 5. Transport cost for materials used and fertilizers

\begin{tabular}{lccc}
\hline Crop & Leyte & Samar & Bohol \\
\hline Tomato & 111.67 & 200.00 & 83.76 \\
Sweet pepper & 54.44 & 100.00 & 80.83 \\
Eggplant & 133.44 & 79.00 & 77.80 \\
Bitter gourd & 189.57 & 156.67 & 71.76 \\
\hline Average & 122.28 & 133.92 & 78.54 \\
\hline
\end{tabular}

Table 6. Distance and travel time to market from production

\begin{tabular}{lccc}
\hline & Leyte & Samar & Bohol \\
\cline { 2 - 3 } & Mean & Mean & Mean \\
\hline Distance in kilometers & 10.14 & 6.48 & 7.36 \\
Travel time (minutes) & 39.80 & 22.13 & 25.25 \\
\hline
\end{tabular}

\section{Average yield per crop}

Table 7 shows the yield of the different crops standardized to output per $1000 \mathrm{~m}^{2}$. Yield in Leyte and Bohol for tomato is relatively higher than in Samar. The total yield for tomato in Leyte is around $716 \mathrm{~kg}$ per $1000 \mathrm{~m}^{2}$ and $1636.53 \mathrm{~kg}$ per $1000 \mathrm{~m}^{2}$ for Bohol while for Samar production is relatively low at $265.43 \mathrm{~kg}$ per $1000 \mathrm{~m}^{2}$. For sweet pepper, Bohol has lowest yield per $1,000 \mathrm{~m}^{2}$ farm area. For eggplant, Bohol have relatively higher yield compared to other provinces with an average of $2489.28 \mathrm{~kg}$ per $1000 \mathrm{~m}^{2}$ per cropping. For bitter gourd, Samar farmers have lowest average yield compared to bitter gourd yield in Leyte and Bohol.

Table 7. Production yield per $1,000 \mathrm{~m}^{2}$ of the 4 crops in Leyte, Samar and Bohol

\begin{tabular}{lrcc}
\hline Yield per Crop & Leyte $(\mathrm{kg})$ & Samar $(\mathrm{kg})$ & Bohol $(\mathrm{kg})$ \\
\hline Tomato & 716.20 & 265.43 & 1636.53 \\
Sweet pepper & 1236.78 & 1426.83 & 1013.56 \\
Eggplant & 794.71 & 649.24 & 2489.28 \\
Bitter gourd & 1882.25 & 1314.89 & 1409.19 \\
\hline
\end{tabular}




\section{Gross Margin Analysis}

For gross margin analysis, the yield per cropping was standardized to yield per $1000 \mathrm{~m}^{2}$. Table 8 presents the gross margin analysis of tomato. The gross revenue is estimated using the market price of tomato multiplied by production (in $\mathrm{kg}$ ). To reduce variation in revenue, the prices used in the computation is based on the published prices of vegetables available in the Philippine Statistics Authority. The publish price for tomato as of February 2018 is PHP40 per kilo. Yield of tomato in Samar is on average $352.56 \mathrm{~kg}$. This yield is relatively low compared to Leyte $836.69 \mathrm{~kg}$ and Bohol with relatively higher yield of $1210.71 \mathrm{~kg}$.

The results show that the gross margin of tomato for Samar is the lowest among three provinces at PHP6,675.16 per $1,000 \mathrm{~m}^{2}$. Leyte has an average gross margin of PHP17,961.40 per $1,000 \mathrm{~m}^{2}$ while Bohol farmers have the highest gross margin on tomato at PHP32,112.68 per $1,000 \mathrm{~m}^{2}$.

On a per hectare basis, the gross margin analysis for $1,000 \mathrm{~m}^{2}$ was multiplied by 10 to get a per hectare value. On a very small-scale level, the gross margin was also computed on $50 \mathrm{~m}^{2}$ farm area. Gross margin analysis was also conducted for sweet pepper, eggplant and bitter gourd.

Table 8. Gross margin analysis for tomato in Leyte, Samar and Bohol per cropping

\begin{tabular}{lccc}
\hline Items & Leyte & Samar & Bohol \\
\hline A. Yield (kg) & 836.69 & 352.56 & 1210.71 \\
Price* & 40 & 40 & 40 \\
Revenue & $33,467.60$ & $14,102.40$ & $48,428.40$ \\
\hline B. Variable cost & & \\
\hline Labor & 10736.14 & 6875.71 & 13536.27 \\
Materials & 4347.82 & 251.53 & 1638.91 \\
Transportation & 111.67 & 200 & 83.76 \\
Marketing & 310.57 & 100 & 1056.78 \\
\hline TOTAL & 15,506 & 7,427 & 16,316 \\
\hline C. Gross Margin (GM) & & & $32,112.68$ \\
\hline (A-B) per $1000 \mathrm{~m}^{2}$ & $17,961.40$ & $6,675.16$ & 1605.634 \\
GM per 50m & 898.07 & 333.758 & $321,126.80$ \\
GM per hectare & $179,614.00$ & $66,751.60$ & \\
\hline
\end{tabular}

*Price was based from Philippine Statistics Authority as of February 2018.

\section{Regression Results in Analyzing Factors Affecting Profitability}

Regression analysis was conducted to determine significant factors that influence profitability of small-scale vegetable productions. Due to inherent differences in practices, separate regression analysis was conducted for tomato, sweet pepper, eggplant and bitter gourd.

Table 9 presents the regression results for the profitability analysis of smallscale tomato production. Results show that the only significant variable that affects profitability of tomato is when the produce of the farmer has a regular buyer. 
Factors affecting profitability of small-scale vegetable production in the Visayas

Profitability measured in terms of gross margin will be a positively influenced by the presence of a regular buyer. This means that the tomato farmers would have significant increase in profit if they have an outlet for their produce as compared to farmers who have no market outlet for their produce. Vegetable farmers are at an advantage if they can market their produce. Hence in order to improve profitability in vegetable production, it is important that there is a good market access. Table 9 presents the summary results of the regression analysis for tomato.

Table 9. Regression analysis of factors affecting profitability of tomato

\begin{tabular}{lcc}
\hline Variables & Coefficients & Standard Error \\
\hline Household size & -0.123 & 0.585 \\
Children in school & 0.374 & 0.765 \\
Married & 2.414 & 4.823 \\
Age & -0.0321 & 0.077 \\
Male & -0.984 & 2.823 \\
Area planted & 0.0015 & 0.0015 \\
Intercrop & -3.260 & 3.597 \\
Multicrop & -0.558 & 2.230 \\
Apply fertilizer & -3.043 & 5.006 \\
Education attained & -0.130 & 0.206 \\
Upland & 0.914 & 3.790 \\
Hilly & -0.418 & 1.549 \\
Apply pesticides & 1.118 & 1.676 \\
Leyte & -1.248 & 3.378 \\
Bohol & 0.776 & 2.360 \\
Market place & 2.933 & 1.881 \\
Regular buyer & $4.174^{\star}$ & 2.386 \\
Traders & 0.761 & 3.200 \\
2017 & -3.426 & 2.695 \\
Constant & 8.511 & 9.852 \\
\hline
\end{tabular}

Note: $n=53$, R-square $=0.266,{ }^{* \star \star}$ Significant at $1 \%$ level, ** significant at $5 \%$ level and * significant at $10 \%$ level.

Regression analysis for profitability of sweet pepper is shown in Table 10. Results show that significant factors affecting profitability of sweet pepper include dummy variables for Bohol farm areas and gender. This implies that vegetable farmers from Bohol are more profitable than vegetable farmers from Samar. Another significant variable that influences profitability is gender, if the vegetable farmer is male, the profitability of the vegetable would likely be higher compared to female farmers. This may be biased for female sweet pepper growers, though this can be observed in a typical agricultural setting where men are more likely to be engaged into farming than women. 
Centes et al

Table 10. Regression analysis of factors affecting profitability of sweet pepper

\begin{tabular}{lcc}
\hline Variables & Coefficients & Standard Error \\
\hline Household size & 0.230 & 0.357 \\
Children in school & 0.508 & 0.735 \\
Married & -2.022 & 2.789 \\
Age & 0.00301 & 0.0679 \\
Male & $3.514^{\star \star}$ & 1.634 \\
Area planted & -0.0001 & 0.0006 \\
Intercrop & -1.052 & 2.155 \\
Multicrop & -1.361 & 1.521 \\
Apply fertilizer & -2.347 & 1.589 \\
Education attained & 0.0214 & 0.155 \\
Upland & 0.948 & 3.067 \\
Hilly & 1.286 & 1.336 \\
Apply pesticides & 0.588 & 1.239 \\
Leyte & 3.949 & 2.407 \\
Bohol & $2.968^{\star}$ & 1.561 \\
Market place & 0.656 & 1.586 \\
Regular buyer & 2.745 & 2.674 \\
Traders & 1.465 & 2.364 \\
2017 & -2.543 & 2.134 \\
Constant & 0.366 & 6.399 \\
\hline
\end{tabular}

Note: $n=65, R$-square $=0.214,{ }^{* \star \star}$ Significant at the $1 \%$ level, ${ }^{* \star}$ Significant at the $5 \%$ level and ${ }^{*}$ Significant at the $10 \%$ level.

Results show that the significant variables that affect profitability for eggplant production includes household size, multi-cropping practice, dummy variables for Samar farm areas and farmers who were reinterviewed during the follow-up survey. Household size shows that it could negatively affect profitability of vegetable production. This may be attributed to the fact that families with more members tends to consume more. Accordingly, farmer with more members may favourably utilize their produce for home consumption instead of selling it, hence lessening their likelihood of gaining profit if marketed. Farm areas in Samar also implies that profitability of eggplant is significantly higher compared to Bohol and Leyte. Baseline respondents who were reinterviewed during the follow-up survey also indicates positive profitability on eggplant production. Another significant variable displaying a positive impact to profitability is the practice of multi-cropping. The practice of multi-cropping suggests that it will result to a higher profitability as compared to mono cropping and intercropping, hence multi-cropping system can maximize the profit that can be derived with limited farm size. Table 11 shows the summary of regression results for eggplant production. 
Factors affecting profitability of small-scale vegetable production in the Visayas

Table 11. Regression analysis of factors affecting profitability of eggplant

\begin{tabular}{lcc}
\hline Variables & Coefficients & Standard Error \\
\hline Household size & $-0.564^{\star \star}$ & 0.272 \\
Children in school & 0.179 & 0.390 \\
Married & 0.715 & 1.625 \\
Age & 0.0102 & 0.039 \\
Area planted & -0.0002 & 0.0002 \\
Intercropping & -0.967 & 2.362 \\
Multicropping & $1.632^{\star}$ & 0.947 \\
Apply fertilizer & 2.345 & 2.703 \\
Education attained & -0.016 & 0.110 \\
Upland & 1.219 & 1.734 \\
Hilly & -0.833 & 0.894 \\
Apply pesticides & 0.526 & 0.839 \\
Leyte & 1.421 & 1.162 \\
Samar & $1.684^{\star}$ & 0.997 \\
Market place & -0.575 & 0.972 \\
Regular buyer & -0.470 & 1.218 \\
Traders & -1.629 & 1.411 \\
2017 & $2.445^{\star}$ & 1.361 \\
Constant & 0.811 & 3.938 \\
\hline
\end{tabular}

Note: $n=135, R$-square $=0.134,{ }^{* \star \star}$ Significant at the $1 \%$ level, ${ }^{* \star}$ Significant at the $5 \%$ level and $*$ Significant at the $10 \%$ level.

Table 12 shows the regression results for profitability analysis of bitter gourd production. Results show that the significant variables that affect profitability of bitter gourd includes intercropping practice, fertilizer application, market outlets, and dummy variable for Samar farm areas. Profitability is significantly higher if vegetable farmers apply fertilizer in their crop. This implies that with the use of fertilizer, production of vegetables will increase, translating to higher profit. Farm areas in Samar also implies positive profitability in bitter gourd production. Having market outlets show a positive impact on profitability. If there is a trader and a regular buyer of the produce, it infers that the vegetable farmers would have significant increase in his profit compared to farmers who has no link to market outlets for their produce. Another significant factor is the practice of intercropping. Practice of intercropping shows that it will result to a higher profitability as compared to mono cropping. Hence, intercropping system can also help maximize the profit that can be derived with smaller farm areas. 
Table 12. Regression analysis of factors affecting profitability of bitter gourd

\begin{tabular}{lcc}
\hline Variables & Coefficients & Standard Error \\
\hline Household size & -0.0447 & 0.383 \\
Children in school & -0.202 & 0.474 \\
Married & -0.347 & 2.481 \\
Age & -0.046 & 0.047 \\
Male & 1.046 & 1.601 \\
Area planted & 0.0001 & 0.0004 \\
Intercropping & $4.989^{\star *}$ & 2.019 \\
Multicropping & 0.349 & 1.239 \\
Apply fertilizer & $8.556^{\star *}$ & 3.58 \\
Education attained & -0.171 & 0.145 \\
Upland & 1.292 & 1.763 \\
Hilly & 1.033 & 1.156 \\
Apply pesticides & 0.220 & 1.173 \\
Leyte & -0.150 & 1.581 \\
Samar & $3.149^{\star \star}$ & 1.409 \\
Market place & 1.939 & 1.406 \\
Regular buyer & $3.045^{\star}$ & 1.634 \\
Traders & $3.974^{\star \star}$ & 1.979 \\
2017 & -0.323 & 1.394 \\
Constant & -3.671 & 5.341 \\
\hline
\end{tabular}

Note: $n=79, R$-square $=0.310,{ }^{* \star}$ Significant at the $1 \%$ level, ${ }^{* \star}$ Significant at the $5 \%$ level and ${ }^{*}$ Significant at the $10 \%$ level.

\section{SUMMARY AND CONCLUSION}

The study was conducted to assess the profitability of small-scale vegetable production in the Visayas particularly in the islands of Bohol, Leyte and Samar. Specifically, it aimed to provide baseline information on farm practices that affects profitability of small-scale vegetable farmers, determine the gross margin of selected vegetables such as, tomato, sweet pepper, eggplant, and bitter gourd and identify factors that affect the profitability of vegetable production.

To address the objectives of the study, data from 311 farmer respondents in Bohol, Leyte and Samar was used. This study focuses on the four main vegetable such as tomato, sweet pepper, eggplant and bitter gourd. These vegetables are the most common vegetables planted in Bohol, Leyte and Samar. Profitability of vegetable production was assessed using gross margin analysis while regression analysis was used to determine the factors that influence profitability of vegetable production in Bohol, Leyte and Samar.

The profitability of vegetable farming is dependent on appropriate cropping practices, marketing and management practices. Results from regression analysis show that cropping practices and market outlets are the significant factors affecting productivity. Results suggest that holding other factors constant, cropping practices such as intercropping and multi-cropping can help increase profitability. Since the analysis focused on small-scale vegetable production, the challenge is to identify which vegetables would perform better in a multi-cropping 
Factors affecting profitability of small-scale vegetable production in the Visayas

and intercropping set-up. With multi-cropping and intercropping, farmers can maximize the yield from their small farms. In addition to these cropping strategies, presence of a regular market outlet significantly affects profitability. This suggests that if farmers have better access to market, vegetable profitability is relatively higher compared to those farmers who were not able to link their production to the market.

The descriptive analysis shows that on average vegetable farmers are relatively far from market. The longer the distance from the site of productions to market or poor access roads negatively affects the quality of perishable produce like tomato, sweet pepper, eggplant and bitter gourd. Hence, improving farm to market road is a good policy option the government can offer. It will help boost the profitability of small-scale vegetable farmers.

\section{ACKNOWLEDGMENT}

We would like to acknowledge the financial support from ACIAR-ICM project and the guidance of Dr. Gordon Rogers and Dr. Sandra MacDougall. The cooperation of other project collaborators, LGU's, farmer respondents and enumerators are gratefully acknowledged. Also the active participation of BISUBilar, Landcare Philippines and Eastwest Seed Company enormously helped the conduct of the baseline survey.

\section{REFERENCES}

Barrett DM. 2006. Maximizing the Nutritional Value of Fruits \& Vegetables Review of literature on nutritional value of produce compares fresh, frozen, and canned products and indicates areas for further research. Department of Food Science and Technology, University of California

Batt PJ, Concepcion S, Dagupen K, Lizada MC \& Murray-Prior R. 2007. The Vegetable Industry in the Philippines (pp63). Final Report, published by ACIAR GPO Box 1571 Canberra ACT 2601Australia

Carating RB, Fernando M, Abrina Y \& Tejada SQ. 2010. State of Organic Agriculture In The Philippines: The Philippine Country Report. Paper presented during the Workshop on ANSOFT of AFACI PAN-ASIAN Project 29-30 November 2010, Suwon, the Republic of Korea

Jagelavicius G. 2013. Gross Margin Management Framework for Merchandising Decisions in Companies with Large Assortment of Products, Gediminas Kaunas University of Technology, Lithuania. http://dx.doi.org/10.5755/j0 1.em.18.1.4116

McDougall S and Rogers G. 2012. Integrated Crop Management to Enhance Vagetable Profitability and Food Security in the Southern Philippines and Australia. Project Proposal HORT 2012/020

Seriño MN, Castillo G \& Ruales JH. 2017. Survey on practices of small-scale vegetable farmers in the Southern Philippines. Annals of Tropical Research 39 ( Supplement B): 1-21

Seriño MN. 2017. Effects of Affluence on Rising Household Carbon Emission in the Philippines: An Application Using Quantile Regression Approach. DLSU Business \& Economics Review 26(2):147-157 